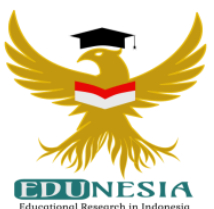

\title{
Kemampuan Memahami Wacana Lisan Dalam Dialog Interaktif Menggunakan Media Rekaman Pada Siswa SMPS Muhammadiyah Ende
}

\author{
Maria Floriana Serlin'; Zaenab Jamaludin² \\ 1,2Pendidikan Bahasa dan Sastra, Universitas Flores, Indonesia \\ ${ }^{1}$ Corresponding Email: maeriaflorianaserlin6@gmail.com, Phone Number :0823 xxxxxxxx
}

\author{
Article History: \\ Received: Nov 11, 2020 \\ Revised: Dec 13, 2020 \\ Accepted: Dec 16, 2020 \\ Published: Jan 01, 2021
}

Keywords:

Oral discourse, Interactive

dialogue, recording

Kata Kunci:

Wacana lisan, dialog

interaktif, rekaman

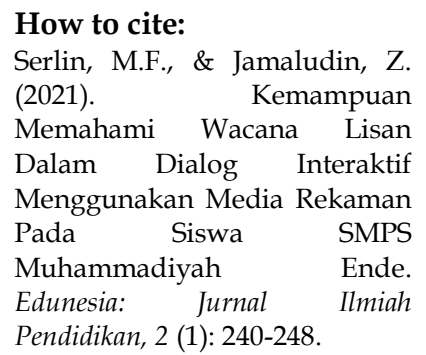

This is an open access article under the $C C-B Y-N C-N D$ license (c) $(9)$

\begin{abstract}
This study aims to determine the ability to understand oral discourse in interactive dialogue using recording media in class VII students of SMPS Muhammadiyah Ende, Ende Utara District, Ende Regency in the 2019/2020 academic year. The specific purpose of this writing is that researchers know the ability to understand oral discourse in interactive dialogue using recording media in class VII students of private SMP Muhammadiyah Ende, Ende Utara District, Ende Regency. The approach used in this research is a quantitative approach. Data were collected using the instrument test method. Data collection techniques using test techniques. The theory used by the writer is listening skill theory and learning evaluation theory.The results of the data analysis show that students can understand oral discourse in interactive dialogue using recorded media. Their ability is classified as good with the average value obtained is $76.96 \%$. Students who are able to get a value of $>75$ with a percentage of $84.31 \%$ with a good predicate and students who are unable to get a value of $<75$ with a percentage of $15.69 \%$ with a sufficient predicate.
\end{abstract}

Abstrak: Penelitian ini bertujuan untuk mengetahui kemampuan memahami wacana lisan dalam dialog interaktif menggunakan media rekaman pada siswa kelas VII SMPS Muhammadiyah Ende Kecamatan Ende Utara Kabupaten Endetahun pembelajaran 2019/2020. Pendekatan yang digunakan dalam penelitian ini adalah pendekatan kuantitatif. Data dikumpulkan dengan menggunakan metode tes esay. Setelah data dikumpulkan selanjutnya data dianalisis dengan menggunakan teknik statistik menggunakan rumus yang dikemukakan oleh Rikwan \& Akdon (2010:28). Hasil analisis data menunjukkan bahwa siswa dapat memahami wacana lisan dalam dialog interaktif menggunakan media rekaman. Kemampuan mereka tergolong baik dengan nilai rata-rata yang diperoleh adalah $76,96 \%$. Siswa yang mampu memperoleh nilai $>75$ dengan persentase $84,31 \%$ dengan predikat baik dan siswa yang tidak mampu memperoleh nilai $<75$ dengan persentase $15,69 \%$ dengan predikat cukup. 


\section{A. Pendahuluan}

Menyimak merupakan salah satu di antara keempat keterampilan berbahasa yang lainnya seperti, menulis, membaca, dan berbicara. Menyimak memiliki makna mendengarkan atau memperhatikan baik-baik apa yang dikatakan orang lain. Jelas faktor kesengajaan dalam kegiatan menyimak lebih besar daripada mendengarkan karena dalam kegiatan menyimak ada usaha untuk memahami apa yang disimaknya, sedangkan dalam kegiatan mendengarkan tingkat kepahamannya belum ada. Dalam kegiatan menyimak bunyi bahasa yang tertangkap oleh alat pendengar lalu diidentifikasi, dikelompokan menjadi suku kata, kata frase, klausa, kalimat dan akhirnya menjadi wacana (Sutari, 2011).

Menyimak sebagai proses mendengarkan, mengenal, serta menginterpretasikan lambang-lambang lisan. Menyimak bermakna mendengarkan dengan penuh pemahaman dan perhatian serta apresiasi. Menurut Tarigan (2010), Menyimak merupakan sarana untuk menerima informasi yang berhubungan dengan kegiatan komunikasi lisan, yang bertujuan untuk memperoleh informasi, menangkap isi atau pesan, dan memahami makna komunikasi (Tarigan, 2010). Dari uraian di atas dapat ditarik kesimpulan bahwa menyimak adalah suatu proses kegiatan mendengarkan lambang-lambang lisan dengan penuh perhatian, pemahaman, apresiasi, serta interpretasi untuk memperolehinformasi, menangkap isi atau pesan, serta memahami makna komunikasi yang telah disampaikan sang pembicara melalui ujaran lisan.

Menurut Srickland dalam Tarigan (2010) ada sembilan tahap dalam kegiatan menyimak di antaranya; (1) menyimak berkala, (2) menyimak dengan perhatian berkala, (3) setengah menyimak, (4) menyimak serapan, (5) menyimak sekali-sekali, (6) menyimak asosiatif, (7) menyimak dengan reaksi berkala, (8) menyimak secara seksama, dan (9) menyimak secara aktif.

Ada dua ragam menyimak yaitu menyimak ekstensifdan menyimak intensif. Kalau menyimak ekstensif lebih diarahkan pada kegiatan menyimak secara lebih bebas dan lebih umum serta perlu di bawah bimbingan langsung para guru, menyimak intensif diarahkan pada suatu kegiatan yang jauh lebih diawasi, dikontrol terhadap satu hal.

Tarigan (2010) mengatakan bahwa menyimak adalah suatu proses kegiatan mendengarkan lambang-lambang lisan dengan penuh perhatian, pemahaman, apresiasi, serta interpretasi untuk memperoleh informasi, menangkap isi, serta memahami makna komunikasi yang tidak disampaikan pembicara melalui ujaran atau bahasa lisan. Berdasarkan pendapat para ahli diatas dapat disimpulkan bahwa menyimak adalah mendengarkan lambang-lambang bunyi yang dilakukan dengan sengaja dan penuh perhatian dengan disertai pemahaman, apresiasi, interpertasi, reaksi dan evaluasi untuk memperoleh pesan, informasi, menangkap isi dan merespon makna yang terkandung di dalam sebuah wacana lisan.

Wacana lisan atau spoken discourse adalah wacana yang disampaikan secara lisan melalui media lisan untuk menerima, memahami atau menikmati, maka para penerima harus menyimak atau mendengarkannya. Dengan kata lain, pendengar adalah penyimak. Wacana lisan ini sering dikaitkan pula dengan interactive discourse atau wacana interaktif. Menurut Sumarlam (2010) wacana lisan merupakan wacana yang disampaikan dengan bahasa lisan atau melalui media lisan. Untuk dapat memahami wacana lisan maka sang penerima harus menyimak atau mendengarkannya. Di dalam wacana lisan, terjadi komunikasi antara pembicara dengan pendengar. Berdasarkan sifat atau jenis pemakaiannya wacana lisan dapat dibedakan diantaranya wacana monolog 
dan wacana dialog. Dengan demikian dapat disimpulkan bahwa wacana lisan merupakan wacana yang disampaikan secara lisan atau secara langsung kepada penerima atau pendengar, serta memiliki perbedaan berdasarkan sifat pemakaiannya yakni wacana monolog (berbicara) dan wacana dialog seperti dialog interaktif.

Dialog interaktif merupakan sebuah perbincangan atau percakapan yang dilakukan pada sebuah acara di televisi atau radio antara pembawa acara dengan pendengar atau pemirsa melalui sambungan telepon. Dialog interaktif melibatkan beberapa pihak, diantaranya pembawa acara yang berperan sebagai moderator, narasumber sebagai penyampai materi, dan pemirsa sebagai penanya.Dialog interaktif biasanya membahas suatu tema atau topik mengenai suatu permasalahan yang sedang menjadi pembicaraan dalam masyarakat tetapi bisa juga mengenai topik-topik tertentu, seperti olahraga, gaya hidup dan hobi. Sama halnya dengan sebuah berita dialog interaktif juga memiliki unsur-unsur pembangun, yaitu unsur $5 \mathrm{~W}+1 \mathrm{H}$ (what, who, when, where, why, dan how). Di dalam kelas terdapat aneka macam kegiatan yang dapat menghalangi kegiatan menyimak misalnya suara bisikan, suara gesekan kursi, atau suara bersin, dan lain-lain. Disinilah guru berperan untuk menaklukkan semua gangguan yang ada. Guru memusatkan perhatian, pikiran, penalaran, penafsiran dan imajinasi siswa pada rekaman dialog interaktif yang diputarkan agar butir-butir pesannya dapat ditangkap, dicerna dan dipahami oleh siswa. Sehingga pada akhir kegiatan pembelajaran siswa mampu menyimpulkan pikiran, pendapat, dan gagasan narasumber dengan tepat.

Permasalahan yang dirumuskan dalam penelitian ini adalah "Bagaimanakah Kemampuan Memahami Wacana Lisan dalam Dialog Interaktif Pada Siswa Kelas VII SMPS Muhammadiyah Ende Kecamatan Ende Utara Kabupaten Ende Tahun Pembelajaran 2019/2020?". Secara umum penelitian ini bertujuan untuk mengetahui kemampuan memahami wacana lisan dalam dialog interaktif pada siswa kelas VII SMP Swasta Muhammadiyah Ende Kecamatan Ende Utara Kabupaten Ende tahun pembelajaran2019/2020. Adapun objek dalam penelitian ini adalah siswa kelas VII SMPS Muhammadiyah Ende yang mana dalam proses kegiatan pembelajaran memahami wacana lisan dalam dialog interaktif selama ini belum menggunakan media apapun.Penggunaan media pembelajaran yang tidak tepat dapat menyebabkan pada akhir kegiatan pembelajaran siswa tidak mampu menyimpulkan pikiran, pendapat, dan gagasan narasumber dengan tepat. Berdasarkan uraian latar belakang di atas maka peneliti berkesimpulan bahwa siswa SMPS Muhammadiyah Ende membutuhkan media yang tepat seperti media rekaman agar dapat menyimak dan memahami wacana lisan dalam dialog inteaktif dengan baik. Penggunaan media rekaman pada pembelajaran menyimak wacana lisan dalam dialog interaktif sekiranya dapat memberi rangsangan kepada siswa untuk dapat menyimak dengan baik.

\section{B. Metode}

Pendekatan yang digunakan dalam penelitian ini adalah pendekatan kuantitatif. Pendekatan kuantitatif merupakan suatu proses menemukan pengetahuan yang menggunakan data berupa angka-angka sebagai alat menganalisis keterangan yang ingin diketahui berpijak pada logika dengan mengedepankan angka-angka yang kebenarannya teruji, terukur, dan teramati (Kasiran, 2010). 
Populasi di dalam penelitian ini adalah siswa kelas VII SMPS Muhammadiyah Ende Tahun Pembelajaran 2019/2020 berjumlah 51 orang. Sampel yang diambil dalam penelitian ini adalah siswa kelas VII SMPS Muhammadiyah Ende Tahun Pembelajaran 2019/2020 berjumlah 51orang. Metode yang digunakan dalam penelitian ini adalah metode tes. Tes adalah teknik pengukuran yang didalamnya terdapat berbagai pertanyaan, pernyataan, atau serangkaian tugas yang harus dikerjakan atau dijawab oleh responden (Arifin, 2012). Tes yang digunakan dalam penelitian ini adalah tes essay. Teknik pengumpulan data yang dilakukan dalam penelitian ini adalah teknik tes. Teknik tes yang digunakan adalah tes prestasi (achievement test) yaitu tes yang dipakai untuk mengukur pencapaian prestasi seseorang. Penggunaan teknik tes ini bertujuan untuk mengetahui kemampuan memahami wacana lisan siswa kelas VII SMPS Muhammadiyah Ende Tahun Pembelajaran 2019/2020. Adapun langkah-langkah dalam proses pembelajaran pada penelitian ini sebagai berikut.

1) Guru memutar rekaman dialog interaktif di depan kelas kemudian meminta siswa untukmendengarkan.

2) Setelah siswa mendengarkan rekaman dialog intreraktif, siswa diminta untuk mendata berbagai pikiran, pendapat, dan gagasan narasumber beserta kesimpulannya terhadap wawancara yang didengar.

3) Siswa diminta untuk menuliskan informasi yang terdapat dalam wawancara yang didengar.

4) Terakhir guru mengumpulkan hasil pekerjaan siswa.

Adapun instrumen penilaian yang digunakan dalam penelitian ini adalah:

Tabel 1. Instrumen penilaian

\begin{tabular}{|c|c|c|}
\hline No & Aspek yang dinilai & Skor \\
\hline 1. & Pikiran, pendapat, dan gagasan narasumber & 60 \\
\hline 2. & $\begin{array}{l}\text { Kesimpulan pikiran, pendapat dan gagasan } \\
\text { narasumber }\end{array}$ & 40 \\
\hline & Jumlah & 100 \\
\hline
\end{tabular}

Setelah data dikumpulkan melalui teknik tes,selanjutnya data dianalisis untuk mengetahui kemampuan siswa dalam memahami kemampuan memahami wacana lisan dalam dialog interaktif pada siswa kelas VII SMPS Muhammadiyah Ende Tahun pembelajaran 2019/2020. Data dianalisis secara statistik menggunakan rumus Ridwan dan Akdon (2010). Perhitungan persentase nilai digunakan untuk menganalisis kemampuan memahami wacana lisan dalam dialog interaktif. Adapun rumus yang digunakan untuk menghitung persentase keberhasilan siswa adalah sebagai berikut.

1) Untuk mengetahui persentase siswa yang mampu

$$
=\frac{\text { Jumlah Siswa yang mampu }}{\text { jumlah sampel }} \times 100 \%
$$

2) Untuk mengetahui persentase siswa yang tidak mampu 


$$
=\frac{\text { Jumlah Siswa yang tidak mampu }}{\text { jumlah sampel }} \times 100 \%
$$

\section{Hasil dan Pembahasan}

Pada bagian ini menyajikan pembahasan tentang hasil penelitian. Pembahasan difokuskan kepada tingkat kemampuan memahami wacana lisan dalam dialog interaktif menggunakan media rekaman. Dalam kegiatan pembelajaran peneliti menjeleskan tentang materi pembelajaran, cara mendata berbagai pendapat, pikiran dan gagasan narasumber dalam wawancara dan cara menyimpulkan pikiran, pendapat dan gagasan narasumber dalam wawancara.

Dari data tes kemampuan responden secara individu dapat terlihat berdasarkan isi tabel berikut melalui beberapa kriteria penilaian.

Tabel 2. Hasil tes kemampuan responden dalam memahami wacana lisan dialog interaktif menggunakan media rekaman

\begin{tabular}{ccccc}
\hline Kode siswa & \multicolumn{2}{c}{ Aspek yang dinilai } & $\begin{array}{c}\text { Skor } \\
\text { maksimal }\end{array}$ & \begin{tabular}{c} 
Skor \\
yang \\
\cline { 2 - 3 } dicapai
\end{tabular} \\
$\begin{array}{c}\text { Pikiran, pendapat, } \\
\text { dan gagasan } \\
\text { narasumber }\end{array}$ & $\begin{array}{c}\text { Kesimpulan pikiran, } \\
\text { pendapat, dan } \\
\text { gagasan narasumber }\end{array}$ &
\end{tabular}

\begin{tabular}{lllll}
\hline 01 & 40 & 40 & 100 & 80 \\
\hline 02 & 40 & 40 & 100 & 80 \\
\hline 03 & 40 & 40 & 100 & 80 \\
\hline 04 & 50 & 40 & 100 & 90 \\
\hline 05 & 40 & 40 & 100 & 80 \\
\hline 06 & 60 & 40 & 100 & 100 \\
\hline 07 & 40 & 40 & 100 & 80 \\
\hline 08 & 40 & 40 & 100 & 80 \\
\hline 09 & 60 & 20 & 100 & 80 \\
\hline 10 & 40 & 40 & 100 & 80 \\
\hline 11 & 40 & 40 & 100 & 80 \\
\hline 12 & 60 & 20 & 100 & 80 \\
\hline 13 & 40 & 40 & 100 & 80 \\
\hline 14 & 40 & 40 & 100 & 80 \\
\hline 15 & 60 & 20 & 100 & 80 \\
\hline 16 & 40 & 40 & 100 & 80 \\
\hline 17 & 60 & 20 & 100 & 80 \\
\hline 18 & 60 & 20 & 100 & 80 \\
\hline 19 & 60 & 20 & 100 & 80 \\
\hline 20 & 40 & 30 & 100 & 70 \\
\hline 21 & 40 & 40 & 100 & 80 \\
\hline 22 & 50 & 40 & 100 & 90 \\
\hline 23 & 40 & 40 & 100 & 80 \\
\hline 24 & 50 & 30 & 100 & 80 \\
\hline 25 & 40 & 40 & 100 & 80 \\
\hline & & & & \\
\hline & & & & \\
\hline & 40 & 40 & & \\
\hline
\end{tabular}




\begin{tabular}{|c|c|c|c|c|}
\hline \multirow{2}{*}{ Kode siswa } & \multicolumn{2}{|c|}{ Aspek yang dinilai } & \multirow{2}{*}{$\begin{array}{c}\text { Skor } \\
\text { maksimal }\end{array}$} & \multirow{2}{*}{$\begin{array}{l}\text { Skor } \\
\text { yang } \\
\text { dicapai }\end{array}$} \\
\hline & $\begin{array}{c}\text { Pikiran, pendapat, } \\
\text { dan gagasan } \\
\text { narasumber }\end{array}$ & $\begin{array}{l}\text { Kesimpulan pikiran, } \\
\text { pendapat, dan } \\
\text { gagasan narasumber }\end{array}$ & & \\
\hline
\end{tabular}

\begin{tabular}{|c|c|c|c|c|}
\hline 26 & 60 & 30 & 100 & 90 \\
\hline 27 & 40 & 40 & 100 & 80 \\
\hline 28 & 60 & 30 & 100 & 90 \\
\hline 29 & 30 & 5 & 100 & 35 \\
\hline 30 & 60 & 20 & 100 & 80 \\
\hline 31 & 50 & 30 & 100 & 80 \\
\hline 32 & 50 & 30 & 100 & 80 \\
\hline 33 & 30 & 5 & 100 & 35 \\
\hline 34 & 40 & 40 & 100 & 90 \\
\hline 35 & 30 & 30 & 100 & 60 \\
\hline 36 & 50 & 30 & 100 & 80 \\
\hline 37 & 50 & 20 & 100 & 70 \\
\hline 38 & 50 & 30 & 100 & 80 \\
\hline 39 & 50 & 30 & 100 & 80 \\
\hline 40 & 10 & 5 & 100 & 15 \\
\hline 41 & 40 & 40 & 100 & 80 \\
\hline 42 & 40 & 40 & 100 & 80 \\
\hline 43 & 30 & 20 & 100 & 50 \\
\hline 44 & 60 & 40 & 100 & 100 \\
\hline 45 & 30 & 20 & 100 & 50 \\
\hline 46 & 60 & 30 & 100 & 90 \\
\hline 47 & 40 & 40 & 100 & 80 \\
\hline 48 & 40 & 40 & 100 & 80 \\
\hline 49 & 60 & 20 & 100 & 80 \\
\hline 50 & 50 & 30 & 100 & 80 \\
\hline 51 & 40 & 40 & 100 & 80 \\
\hline Jumlah & 2320 & 1595 & & 3925 \\
\hline Rata-Rata & 45,49 & 31,27 & & 76,96 \\
\hline
\end{tabular}

Dengan demikian rata-rata kedua aspek penilaian berdasarkan tabel 2 adalah 76,96 dengan penjelasan sebagai berikut:

1) Rata-rata kemampuan memahami wacana lisan dalam dialog interaktif siswa kelas VII SMP Swasta Muhammadiyah Ende Kecamatan Ende Utara Kabupaten Ende pada aspek pikiran, pendapat, dan gagasan narasumber dengan rata-rata mencapai nilai 45,49 diperoleh dari jumlah skor / jumlah siswa $(2320 / 51=45,49)$.

2) Rata-rata kemampuan memahami wacana lisan dalam dialog interaktif siswa kelas VII SMP Swasta Muhamadiyah Ende Kecamatan Ende Utara Kabupaten Ende pada aspek kesimpulan pikiran, pendapat, dan gagasan narasumber dengan rata-rata mencapai nilai 31,27 diperoleh dari jumlah skor / jumlah siswa ( 1595 / 51 =31,27). 
3) Berdasarkan pada persentase yang mampu dan tidak mampu siswa, dapat dilihat hasil penilaian setiap siswa yang disesuaiakan dengan standar ketuntasan maksimum yang telah ditetapkan, yaitu siswa yang berhasil mencapai nilai $>75$ dan siswa yang belum berhasil mencapai nilai $<75$.

4) Persentase siswa yang mampu adalah $84,31 \%$

5) Persentase siswa yang tidak mampu adalah $15,69 \%$

Tabel 3.

Persentase Siswa Yang Mampu dan Siswa Yang Tidak Mampu dalamMemahami Wacana Lisan dalam Dialog Interaktif

\begin{tabular}{cccc}
\hline No & Mampu dan Tidak Mampu & Jumlah Siswa & Presentase \\
\hline 1. & Siswa Mampu & 43 & $\mathbf{8 4 , 3 1 \%}$ \\
\hline 2. & Siswa Tidak Mampu & $\mathbf{8}$ & $\mathbf{1 5 , 6 9 \%}$ \\
\hline
\end{tabular}

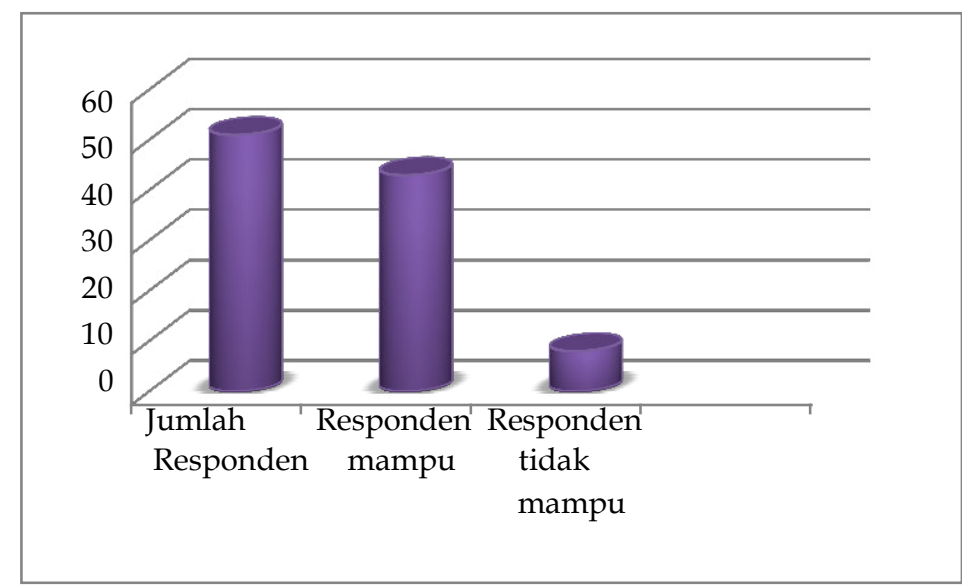

Gambar 1.

Persentase responden yang mampu dan yang tidak mampu dalam memahami wacana lisan dalam dialog interaktif menggunakan media rekaman

Berdasarkan data pada tabel 3 dan gambar 1 diketahui bahwa siswa yang mampu adalah 43 orang dengan persentase $84,31 \%$ diperoleh dari jumlah siswa yang mampu per jumlah siswa sampel dikali $100 \%$ sedangkan siswa yang tidak mampu 8 orang dengan presentase $15,69 \%$ diperoleh dari jumlah siswa yang tidak mampu perjumlah siswa sampel dikali $100 \%$.

Setelah data dianalisis berdasarkan persentase yang mampu dan tidak mampu, selanjutnya peneliti mengklasifikasikan nilai berdasarkan tabel nilai arti tingkat penguasaan siswa dalam memahami wacana lisan dalam dialog interaktif berdasarkan rata-rata dari nilai yang di peroleh siswa. Lima aspek penilaian yang terlihat pada tabel di bawah ini: 
Tabel 4. Nilai arti tingkat penguasaan

\begin{tabular}{ccccc|}
\hline No & Kategori Nilai & Predikat & $\begin{array}{c}\text { Jumlah } \\
\text { Siswa }\end{array}$ & $\begin{array}{c}\text { Rata-Rata } \\
\text { Nilai Siswa } \\
\text { Sampel }\end{array}$ \\
\hline 1 & $90-100$ & $\begin{array}{c}\text { Sangat } \\
\text { baik }\end{array}$ & - & \\
\hline 2 & $80-89$ & Baik & 51 & $76,96 \%$ \\
\hline 3 & $70-79$ & Cukup & - & \\
\hline 4 & $<70$ & Kurang & - & \\
\hline
\end{tabular}

Sesuai uraian pada tabel 4 dapat disimpulkan bahwa dari 51 siswa sampel yang merupakan siswa kelas VII SMP Swasta Muhammadiyah Ende dalam hal memahami wacana lisan dalam dialog interaktif menggunakan media rekaman memperoleh nilai rata-rata $76,96 \%$ dengan predikat baik.

\section{Kesimpulan}

Berdasarkan hasil tes terhadap 51 siswa sampel, peneliti mengklasifikasikan nilai perolehan siswa sampel berdasarkan masing- masing aspek penilaian, yakni:

1) Untuk aspek ketepatan data dengan rata-rata mencapai nilai 2320 dengan persentase $45,49 \%$, jadi dapat disimpulkan bahwa nilai dilihat dari aspek ini adalah baik.

2) Untuk aspek kebenenaran data dan bahasa yang komunikatif dengan rata- rata mencapai nilai 1595 dengan persentase 31,27 \%, jadi dapat disimpulkan bahwa nilai dilihat dari aspek ini adalah baik.

Berdasarkan hasil tes diketahui bahwa nilai rata-rata dari kedua aspek penilaian dalam memahami wacana lisan dalam dialog interaktif menggunakan media rekaman siswa kelas VII SMPS Muhammadiyah Ende Kecamatan Ende Utara Kabupaten Ende Tahun Pembelajaran 2019/2020 adalah 76,96 \% dengan predikat baik.

Pada tabel 3 peneliti menggambarkan dengan jelas persentase tingkat kemampuan dan ketidakmampuan siswa dalam memahami wacana lisan yang didasarkan pada pemerolehan nilai siswa yang disesuaikan dengan kriteria ketuntasan minimum, dimana siswa yang mampu memperoleh nilai $>75$ dan siswa yang tidak mampu memperoleh nilai $<75$.

Setelah melalui proses perhitungan diperoleh data sebagai berikut, dari 51 siswa sampel diketahui siswa yang mampu memperoleh nilai $>75$ sebanyak 43 siswa dengan persentase tingkat yang mampu $84,31 \%$ memperoleh predikat baik. Sedangkan bagi siswa yang tidak mampu memperoleh nilai $<75$ sebanyak 8 siswa dengan persentase tingkat yang tidak mampu $15,69 \%$ memperoleh predikat cukup.

Setelah mengolah data dan menganalisis data melalui metode kuantitatif tentang tingkat kemampuan siswa dalam memahami wacana lisan dalam dialog interaktif menggunakan media rekaman siswa kelas VII SMPS Muhammadiyah Ende Kecamatan Ende Utara Kabupaten Ende Tahun Pembelajaran 2019/2020 maka disimpulkan sebagaiberikut:

1) Siswa yang berhasil mencapai $84,31 \%$ yang menggambarkan keberhasilan siswa pada materi pembelajaran memahami wacana lisan dalam dialog interaktif. 
Keberhasilan ini juga tidak terlepas dari kemauan peneliti untuk mengimplementasikan kegiatan pembelajaran memahami wacana lisan dalam dialog interaktif dan kemauan yang tinggi siswa itu sendiri dalam mengikuti pembelajaran.

2) Siswa yang tidak berhasil mencapai $15,69 \%$. Hal ini dikarenakan kurang adanya perhatian dan kesungguhan saat mengikuti proses pelajaran.

Berdasarkan kesimpulan maka saran yang diajukan dirumuskan sebagai berikut:

1) Bagi Guru Mata Pelajaran Bahasa Indonesia Meningkatkan kinerja dalam mengajar terutama pada kompetensi mendengarkan. Guru harus memusatkan perhatian yang penuh terhadap siswa, karena banyak siswa yang kurang memperhatikan, mendengar, dan menyimak pelajaran dengan baik.

2) Bagi Siswa

Mengikuti pembelajaran dengan penuh perhatian dan sungguh-sungguh, dan memusatkan perhatian hanya pada materi yang diterangkan guru dikelas.

3) Bagi Sekolah

Menerapkan metode pengajaran yang efektif dalam meningkatkan prestasi belajar bahasa Indonesia siswa di sekolah.

\section{Daftar Pustaka}

Adnan,H.T. (2011). Menyimak : Deep Listening. Yogyakarta: Skripta.

Arifin, Z. (2012). Penelitian Pendidikan. Bandung: PT. Remaja Rosdakarya.

Hermawan, H. (2012). Keterampilan Menyimak yang Terabaikan. Yogyakarta: Graha Ilmu.

Ismawati, E. (2012). Metode Penelitian Pendidikan Bahasa E Sastra. Yogyakarta: Penerbit Ombak.

Kasiran. (2010). Metode Penelitian Kualitatif-Kuantitatif. Yogyakarta: UIN-Maliki Press

Moa, Y.S. (2012).Memahami Isi Suatu Wacana Pada Siswa Kelas VII SMPNegeri Detusoko Tahun Ajaran 2012/2013. Ende:Uniflor.

Sumarlam. (2010). Analisis Wacana. Surakarta: Pustaka Cakra.

Ridwan., \& Akdon. (2010). Rumus dan Data dalam Analisis Statistika. Bandung: Alfabeta.

Sugiyono. (2010). Metode Penelitian Kuantitatif-Kualitatif dan R $\mathcal{E}$ D. Bandung: alfabeta .

Suryani, N.,\& Leo, A. (2012). Strategi Belajar Mengajar. Ombak: Jogjakarta.

Sutari, I.K. (2011). Menyimak. Jakarta: Depdikbud.

Tarigan, H.G. (2010). Menyimak sebagai Suatu Keterampilan Berbahasa. Bandung: Penerbit Angkasa. 